\title{
Nursing Care Perception and Satisfaction Levels of Surgical Patients
}

\section{Cerrahi Hastalarının Hemşirelik Bakımını Algılayışı ve Memnuniyet Düzeyleri}

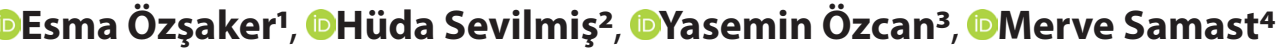 \\ ${ }^{1}$ Ege University Faculty of Nursing, Izmir, Turkey \\ ${ }^{2}$ Giresun University Prof. Dr. A. Illhan Özdemir Training and Research Hospital, Giresun, Turkey \\ ${ }^{3}$ Bozyaka Izmir Training and Research Hospital, Izmir, Turkey \\ ${ }^{4}$ Ege University Medical Faculty Hospital, Izmir, Turkey
}

\begin{abstract}
Objective: This study was conducted to examine the Nursing Care Perception and Satisfaction Levels of Surgical Patients.

Material and Method: The sample of this descriptive and crosssectional study consisted of 300 patients aged 18 and over, who accepted to participate in the study, who were hospitalized at a university hospital surgical clinics between 17 December 2018 and 15 March 2019. Data were collected with the "Patient Information Form" created by the researchers, and "Newcastle Satisfaction with Nursing Care Scale" and "The Scale of Patient Perception of Hospital Experience With Nursing". Percentage, mean, $t$ test, analysis of variance, and Pearson's correlation analysis were used to evaluate the data.
\end{abstract}

Results: Newcastle Satisfaction with Nursing Care Scale mean score of the surgical patients was $79.86 \pm 19.31$ and the mean score of The Scale of Patient Perception of Hospital Experience With Nursing was $68.03 \pm 9.87$. It was found that there was a statistically significant relationship between the score of Newcastle Satisfaction with Nursing Care Scale and the score of The Scale of Patient Perception of Hospital Experience With Nursing $(r=0.665$; $p=0.001$ ). A statistically significant difference was found between the average point of Newcastle Satisfaction with Nursing Care Scale and education level, chronic illness, type of hospitalization, number of patients in the room $(p<0.05)$.

Conclusion: It was found that surgical patients' perception level of nursing care and satisfaction levels with nursing care were high. It was found that patients' perception of nursing care positively affected the nursing care satisfaction level of patients.

Keywords: Surgery, patient, nursing care, satisfaction level
Öz

Amaç: Bu çalışma, cerrahi hastalarının hemşirelik bakımını algılayışını ve memnuniyet düzeylerini incelemek amacıyla yapıldı.

Gereç ve Yöntem: Tanımlayıcı ve kesitsel türdeki bu çalışmanın örneklemini, 17 Aralık 2018- 15 Mart 2019 tarihleri arasında bir üniversite hastanesinin cerrahi kliniklerinde yatan, araştırmaya katılmayı kabul eden, 18 yaş ve üzeri, iletişim kurabilen 300 hasta oluşturdu. Veriler, araştırmacılar tarafından oluşturulan "Hasta Bilgi Formu" ve "Newcastle Hemşirelik Memnuniyet Ölçeği", "Hastaların Hemşirelik Bakımın Algılayış Ölçeği (HHBAÖ)" kullanılarak toplandı. Verilerin değerlendirilmesinde sayı, yüzde, ortalama, standart sapma, Student t testi, varyans analizi ve Pearson's Korelasyon analizi kullanıldı

Bulgular: Cerrahi kliniklerde yatan hastaların; hemşirelik bakımından memnuniyet puan ortalaması 79,86 19,31 ve hemşirelik bakımın algılayışı puan ortalaması 68,03 $\pm 9,87$ olarak bulundu. Hastaların Newcastle hemşirelik bakımından memnuniyet ölçeği toplam puan ortalaması ile hemşirelik bakımını algılayışı ölçeği toplam puan ortalaması arasında pozitif yönde istatistiksel olarak anlamlı bir ilişki saptandı ( $r=0,665 ; p=0,001)$. Eğitim düzeyi, kronik hastalık durumu, hastaneye yatış şekli, odada bulunan hasta sayısı ile hemşirelik bakımından memnuniyet puan ortalamaları arasındaki fark istatistiksel açıdan anlamlı bulundu $(p<0,05)$.

Sonuç: Cerrahi hastalarının hemşirelik bakımını algılama düzeylerinin ve hemşirelik bakımından memnuniyet düzeylerinin yüksek olduğu bulundu. Hastaların hemşirelik bakımına ilişkin algılarının, hemşirelik bakımından memnuniyet düzeylerini olumlu etkilediği belirlendi.

Anahtar Kelimeler: Cerrahi, hasta, hemşirelik bakımı, memnuniyet düzeyl 


\section{INTRODUCTION}

Nurses are members of the health team that play an active role in the management of health care, which also have a vital function of maintaining, improving, and rehabilitating the people's health, and providing uninterrupted services during the patient's stay in the hospital. ${ }^{[1]}$ Nursing care is a professional service that includes the determination, planning, implementation, and evaluation of the care requirements of people with existing or potential health problems by the nurses and includes mutual trust, empathy, privacy, ethical and moral values throughout the entire process of care. Care is an important factor not only in meeting biological needs but also in meeting psychological, social and cultural needs. ${ }^{[2]}$

Surgical interventions cause many physiological and psychological changes in the human body (homeostatic balance, fear, predisposition to infection, pain, etc.). Patients need high-quality nursing care to cope with these changes in the postoperative period. ${ }^{[3]}$ Nurses are the healthcare workers whom surgical patients need most before and after surgery ${ }^{[4]}$ The quality of nursing care is directly related to how the given care service is perceived by the service recipients. ${ }^{[5-8]}$ Besides the individual characteristics of the patients, the support they receive from the nurse, the respect and courtesy shown by the nurse, the ability to reach the nurse when needed, and being informed clearly and satisfactorily are also very effective in terms of care perception. ${ }^{[7,9,10]}$ One of the most important indicators in evaluating the service and care quality offered by healthcare professionals is the patient's satisfaction with the care service. ${ }^{[11-13]}$ Patient satisfaction is determined by the level of perception of the care given in line with the expectations of the patients. ${ }^{[14-}$ ${ }^{16]}$ In the emergence of the perception concerning health service quality in patients, the patients' evaluation of the nursing services is important. According to the widely used definition in the field of nursing, patient satisfaction is the degree of proximity between the patient's expectation of ideal nursing care and the perception of nursing care that they actually received..$^{[1]}$

It is important to systematically evaluate care within the scope of continuous improvement and quality and to share the results with healthcare professionals and managers. In this regard, it is important to periodically measure patient satisfaction, which is an important indicator of the quality of nursing services and therefore health services, and to identify situations that cause dissatisfaction, to produce proper solutions and to make necessary arrangements for nurses' patient care practices. Therefore, this study was conducted as a descriptive study to examine surgical patients' perception of nursing care and their level of satisfaction.

Research questions:

-What is the perception of surgical patients on nursing care?

- What are the satisfaction levels of surgical patients with regard to nursing care?
- Does surgical patients' perception of nursing care affect their satisfaction level?

-What are the factors affecting the nursing care satisfaction level of surgical patients?

\section{MATERIAL AND METHOD}

\section{Design}

This descriptive study was conducted to determine surgical patients' perception of nursing care and their satisfaction levels.

\section{Sample}

The research population was composed of patients hospitalized in the surgical clinics of a university hospital (General Surgery, Urology, Otorhinolaryngology, Orthopedics, Plastic Surgery, Organ Transplantation, Neurosurgery, Thoracic Surgery, Cardiovascular Surgery) between 17 December 2018 and 15 March 2019. The sample of the study consisted of 300 patients who met the research criteria and agreed to participate in the study between the dates determined without using the sampling method.

\section{Inclusion Criteria}

- Agreeing to participate in research,

- Discharged from surgical clinics,

- Spent three days or more in the ward,

- No hearing or vision problems

- 18 years of age and older

- Being able to read and write,

- Patients who can communicate.

\section{Data Collection Tools}

The data were collected using the "Patient Information Form" created by the researchers, "Newcastle Satisfaction with Nursing Scales (NSNS)" and "Patient Perception of Hospital Experience with Nursing Care (PPHEN)".

Patient Information Form: This form, created by the researchers, includes the patients' socio-demographic (age, gender, educational status, marital status, occupation, employment status, place of residence, social security and income status, etc.) and hospitalization (clinic where the patients are hospitalized, their history of prior hospitalization, their application type, the number of patients he/she stayed together in the room where they were treated, the duration of their hospitalization, their operation status, the state of their staying in the intensive care unit and the state of presence of their companion, etc.) is a form consisting of 26 questions that query variables related to their properties.

Newcastle Satisfaction with Nursing Scales (NSNS): NSNCS was developed by Thomas and Bond in 1996 to determine the patient's perspective and experiences and satisfaction with nursing care. The Turkish validity and reliability study was done by Uzun in $2003^{[17]}$ and then by Akın and Erdoğan 
in 2007. ${ }^{[18]}$ This scale is a 5-point Likert-type scale consisting of 19 items to determine satisfaction in terms of nursing. All items are scored on a five-point Likert scale $(1=$ not at all satisfied, 2=barely satisfied, 3=quite satisfied, 4=very satisfied and $5=$ completely satisfied). Total score was summed and transformed to yield an overall 'satisfaction score' of 0-100, where "100" denoted complete satisfaction/highest level of satisfaction with all aspects of nursing care. Cronbach alpha was found as 0.96 in the study of Thomas et al. (1996), was found 0.94 in the study of Uzun (2003), and was found 0.96 in the study of Akın and Erdoğan (2007).

Patient Perception of Hospital Experience with Nursing Care (PPHEN): PPHEN was first developed by Dozier et al in 2001, and the validity-reliability study in Turkey was conducted by Çoban and Kaşıkçı in 2006. ${ }^{[19]}$ There are 15 statements about the quality of nursing care in a Likert-type scale. The questions are assigned scores based on the responses to each statement, as follows: totally agree (5), slightly agree (4), undecided (3), disagree (2), and totally disagree (1). Any unanswered item is evaluated as zero (0). The scale results in a minimum score of 15 and a maximum score of 75 . The cut-off point of the scale is 45. Higher total scores indicate high level of satisfaction with nursing care. In the study of Coban and Kasıkc (2006), Cronbach alpha was found as 0.92. In this study Cronbach alpha was found as 0.95 .

\section{Data Collection}

December March 17, 2018 - March 15, 2019, the patients who accepted to participate in the study were asked to fill out an Informed Voluntary Consent Form, Patient Information Form, NSNS and PPHEN after explaining the research to the patients who decided to be discharged at the surgical clinics of a university Hospital and who met the study criteria. Participation with the questionnaire lasted on average about 10 minutes.

\section{Data Analysis}

The SPSS 25.0 program was used to evaluate the data. Number, percentage, mean, standard deviation, Student's t test, variance analysis and Pearson's Correlation analysis were used to evaluate the data. The resulting $p$-value at $<0.05$ was considered statistically significant.

\section{Ethical Issues}

Ethics committee approval was obtained from the Clinical Research Ethics Committee of the relevant university (Protocol: 20/03/2018, 18-3.1/31), and written permission was obtained from the management of the hospital where the research was conducted (04.06.2018, E. 159252). Informed consent was read and signed by each participant. All principles of the Helsinki declaration were followed throughout the study. Permission was obtained via mail from Uzun, who conducted the Turkish validity and reliability study of the NSNS, and from Çoban, who conducted the Turkish validityreliability study of the PPHEN.

\section{RESULTS}

\section{Findings on Sociodemographic and Hospitalization Characteristics}

When the sociodemographic and hospitalization characteristics of the patients participating in the study were examined; the average age was $52.73 \pm 13.00$ (minimum 18, maximum 66 ), $54.7 \%$ of them were male, $74 \%$ of them were married; It was determined that $38.7 \%$ were high school graduates, $57 \%$ had previous surgery, $41.7 \%$ had a chronic disease, $86 \%$ had someone to give home care. The average hospitalization time of the patients was 13.23 \pm 18.26 days (min. 3, max.165 days), $65.3 \%$ applied to the hospital for a planned surgery, $42.7 \%$ stayed in a private room, $93.7 \%$ had a hospital attendant, $95 \%$ of them had information about surgery, $73.3 \%$ of them found the training sufficient, and $95 \%$ of them were satisfied with the clinic where they were hospitalized (Table 1).

\begin{tabular}{|c|c|c|c|}
\hline Characteristics & Min.-Max. & \multicolumn{2}{|c|}{ Mean \pm SD } \\
\hline Age & $18-66$ & \multicolumn{2}{|c|}{$52.73 \pm 13.00$} \\
\hline Length of hospitalization & 3-165 & \multicolumn{2}{|c|}{$13.23 \pm 18.26$} \\
\hline & & $\mathbf{n}$ & $\%$ \\
\hline Gender & $\begin{array}{l}\text { Female } \\
\text { Male }\end{array}$ & $\begin{array}{l}136 \\
164\end{array}$ & $\begin{array}{l}45.3 \\
54.7\end{array}$ \\
\hline Marital status & $\begin{array}{l}\text { The married } \\
\text { Single }\end{array}$ & $\begin{array}{c}222 \\
78\end{array}$ & $\begin{array}{l}74 \\
26\end{array}$ \\
\hline Education status & $\begin{array}{l}\text { Literate } \\
\text { High school } \\
\text { Primary education } \\
\text { University }\end{array}$ & $\begin{array}{c}44 \\
116 \\
74 \\
66\end{array}$ & $\begin{array}{c}14.7 \\
38,7 \\
24.7 \\
22\end{array}$ \\
\hline Previous surgery & $\begin{array}{l}\text { Yes } \\
\text { No }\end{array}$ & $\begin{array}{l}171 \\
129\end{array}$ & $\begin{array}{l}57 \\
43\end{array}$ \\
\hline Having a chronic illness & $\begin{array}{l}\text { Yes } \\
\text { No }\end{array}$ & $\begin{array}{l}125 \\
175\end{array}$ & $\begin{array}{l}41.7 \\
58.3\end{array}$ \\
\hline $\begin{array}{l}\text { Is there someone to care } \\
\text { at home }\end{array}$ & $\begin{array}{l}\text { Yes } \\
\text { No }\end{array}$ & $\begin{array}{c}258 \\
42\end{array}$ & $\begin{array}{l}86 \\
14\end{array}$ \\
\hline Type of hospitalization & $\begin{array}{l}\text { Urgent } \\
\text { Planned }\end{array}$ & $\begin{array}{l}104 \\
196\end{array}$ & $\begin{array}{l}34.7 \\
65.3\end{array}$ \\
\hline Type of room & $\begin{array}{l}\text { Private room } \\
\text { Double } \\
\text { Three or more people }\end{array}$ & $\begin{array}{c}128 \\
58 \\
114\end{array}$ & $\begin{array}{c}42.7 \\
19.3 \\
38\end{array}$ \\
\hline Companion status & $\begin{array}{l}\text { There is } \\
\text { No }\end{array}$ & $\begin{array}{c}281 \\
19\end{array}$ & $\begin{array}{c}93.7 \\
6.3\end{array}$ \\
\hline $\begin{array}{l}\text { Receiving information } \\
\text { about the operation }\end{array}$ & $\begin{array}{l}\text { Yes } \\
\text { No }\end{array}$ & $\begin{array}{c}285 \\
15\end{array}$ & $\begin{array}{c}95 \\
5\end{array}$ \\
\hline $\begin{array}{l}\text { Is the information given } \\
\text { for the surgery sufficient? }\end{array}$ & $\begin{array}{l}\text { Enough } \\
\text { Partially enough } \\
\text { Not enough }\end{array}$ & $\begin{array}{l}220 \\
63 \\
17\end{array}$ & $\begin{array}{c}73.3 \\
21 \\
5.7\end{array}$ \\
\hline $\begin{array}{l}\text { Are you satisfied with the } \\
\text { surgery clinic you are in. }\end{array}$ & $\begin{array}{l}\text { Yes } \\
\text { No }\end{array}$ & $\begin{array}{c}285 \\
15\end{array}$ & $\begin{array}{c}95 \\
5\end{array}$ \\
\hline
\end{tabular}




\section{Findings Related to Scale Scores}

PPHEN items and the average scores obtained are shown in Table 2, while NSNS items and the mean scores obtained are shown in Table 3. It was determined that the patients got the lowest 23.16 and the highest 100 points in PPHEN and their mean score was $79.86 \pm 19.31$. It was found that patients received the lowest score of 15 and the highest score of 75 from the scale of perception of nursing care, and the mean score was $68.03 \pm 9.87$. It was found that there was a positive, highly significant relationship between the patients' mean NSNS total score and the mean PPHEN total score $(r=0.665 ; p=0.001)$ (Table 4).

Table 2. Patients' opinions on general nursing practices in surgical clinics $(n=300)$

Patient Perception of Hospital Experience with Nursing Care (PPHEN)

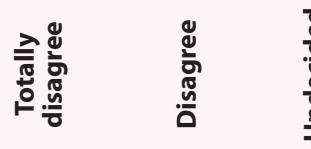

1. The nurses helped my outlook become more realistic

$\begin{array}{cc}\% & \% \\ 1.7 & 4.3\end{array}$

2. The nurses thought ahead about what I needed

3. My requests were promptly attended to by the nursing staff

$1.7 \quad 5.3$

5.3

0.3

3.7

1.3

3.0

3.0

5.3

5. Little things were carried out for me without asking me

7. The nurses helped me better deal with the unknowns of this hospitalisation

$\% \quad \% \quad \%$

10. I feel the nurses understood what this illness means to me

11. I know that because of the nurses' efforts, some problems were avoided.

8.7
8.7

8.7
4.0

18.3

67.0

12. The nursing staff helped me manage the fears I had about my illness

\section{Newcastle Satisfaction with Nursing Scales (NSNS)}

\begin{tabular}{|c|c|c|c|}
\hline 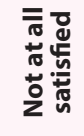 & 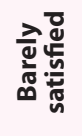 & 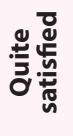 & 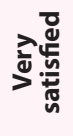 \\
\hline
\end{tabular}

\section{The amount of time spent with you}

2. How capable nurses were at their job

3. There always being a nurse around if you needed one

4. The amount nurses knew about your care

5. How quickly nurses came when you called for them

6. The way the nurses made you feel at home

7. The amount of information nurses gave to you about your condition and treatment

8. How often nurses checked to see if you were okay

9. Nurses' helpfulness

10. The way nurses explained things to you

11. How nurses helped put your relatives' or friends' minds at rest

12. Nurses' manner in going about their work

13. The type of information nurses gave to you about your condition and treatment

14. Nurses' treatment of you as an individual

15. How nurses listened to your worries and concerns

16. The amount of freedom you were given on the ward

17. How willing nurses were to respond to your requests

18. The amount of privacy nurses gave you

19. Nurses' awareness of your needs

\begin{tabular}{ccccc}
$\%$ & $\%$ & $\%$ & $\%$ & $\%$ \\
\hline 2.0 & 10.3 & 20.0 & 29.3 & 38.3 \\
1.3 & 6.7 & 21.7 & 30.3 & 40.0 \\
3.7 & 10.0 & 19.0 & 26.0 & 41.3 \\
1.7 & 9.7 & 15.7 & 30.0 & 43.0 \\
3.7 & 11.7 & 15.0 & 28.0 & 41.7 \\
3.7 & 14.7 & 15.3 & 27.7 & 38.7 \\
3.0 & 11.0 & 19.0 & 28.0 & 39.0 \\
3.3 & 6.7 & 18.7 & 29.3 & 42.0 \\
1.3 & 7.7 & 18.3 & 27.3 & 45.3 \\
0.7 & 8.7 & 18.7 & 27.3 & 44.7 \\
2.0 & 14.0 & 17.0 & 27.0 & 40.0 \\
2.3 & 7.7 & 15.3 & 30.0 & 44.7 \\
1.0 & 12.0 & 15.3 & 31.3 & 40.3 \\
2.3 & 8.3 & 15.3 & 31.3 & 42.7 \\
4.3 & 9.7 & 15.0 & 29.3 & 41.7 \\
3.3 & 6.7 & 18.3 & 28.0 & 43.7 \\
2.3 & 9.3 & 15.0 & 29.3 & 44.0 \\
1.7 & 4.0 & 15.7 & 28.0 & 50.7 \\
1.3 & 10.3 & 16.3 & 28.7 & 43.3 \\
\hline
\end{tabular}


Tablo 4. Distribution of PPHEN and NSNS Mean Scores and Relationship Status Between Scales $(n=300)$

Scale (Points that can be obtained) Min.-Maks.

Received Points

\begin{tabular}{|c|c|c|c|c|}
\hline scale (roints that can ve oveamea) inm.-Inaks. & Mean $\pm S D$ & Min. & Max. & Correlation \\
\hline NSNS (0 -100) & $79.86 \pm 19.31$ & 23.16 & 100 & $r: 0.665^{* *}$ \\
\hline PPHEN (15-75) & $68.03 \pm 9.87$ & 15 & 75 & $\mathrm{p}: 0.001$ \\
\hline
\end{tabular}

PPHEN: Patient Perception of Hospital Experience with Nursing Care, NSNS: Newcastle Satisfaction with Nursing Scales, x: Arithmetic Average, SD: Standard deviation, Min: Minimum value, Max: Maximum value, ${ }^{* *}$ Correlation relation is significant at $p<0.01$ level.

When the mean scores of the PPHEN and NSNS were examined according to the sociodemographic characteristics of the patients, there was a statistically significant difference $(p<0.05)$ between their marital status and PPHEN mean scores, and between educational status and NSNS mean scores; it was seen that there was no statistically significant difference between them according to the patients' gender, employment status, place of residence, and social security status $(p>0.05)$. Besides, when the relationship between chronic disease and nursing care satisfaction was examined; the average score of the nursing care satisfaction scale was found to be significantly higher in patients with chronic disease $(82.56 \pm 18.89)$ than those without $(77.93 \pm 19.43)$ (t: 0.059, p: 0,040). It was determined that the mean NSNS score of the university graduate patients was significantly lower than the primary school graduates $(p<0.05)$ (Table 5).
The relationship between the satisfaction with the services in the surgical clinic where the patients are hospitalized and the variables related to their hospitalization status and the mean NSNS scores are shown in Table 6. According to the way of patients' hospitalization, their numbers in the room, their satisfaction status with the surgical clinic where they lied down and the hospital, medical services, nursing services, other health services, secretarial patient admission, cleaning/order, support, respect and courtesy, the way of getting clear answers to their questions, satisfaction status with accessibility to doctors and nurses, a significant correlation was found between the mean scores of NSNS ( $p$ <.05). In an advanced analysis, it was seen that the satisfaction levels of those staying in a room of three or more people were lower than those who stayed in a private room and a double room.

Table 5. Distribution of PPHEN and NSNS Mean Scores According to Sociodemographic Characteristics of the Patients $(n=300)$

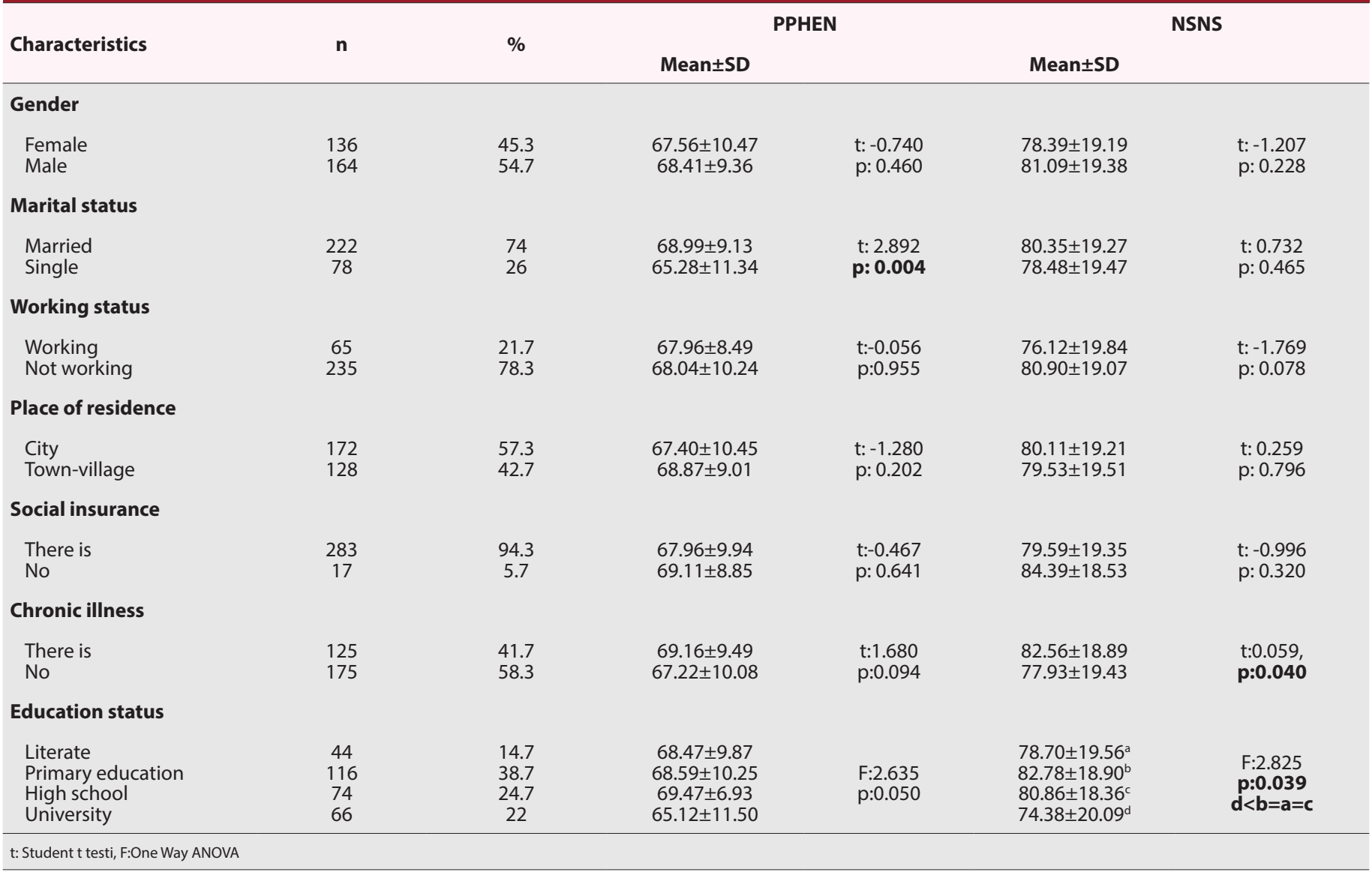


Table 6. Mean NSNS Scores According to Variables Regarding Patients' Hospitalization Status ( $n=300$ )

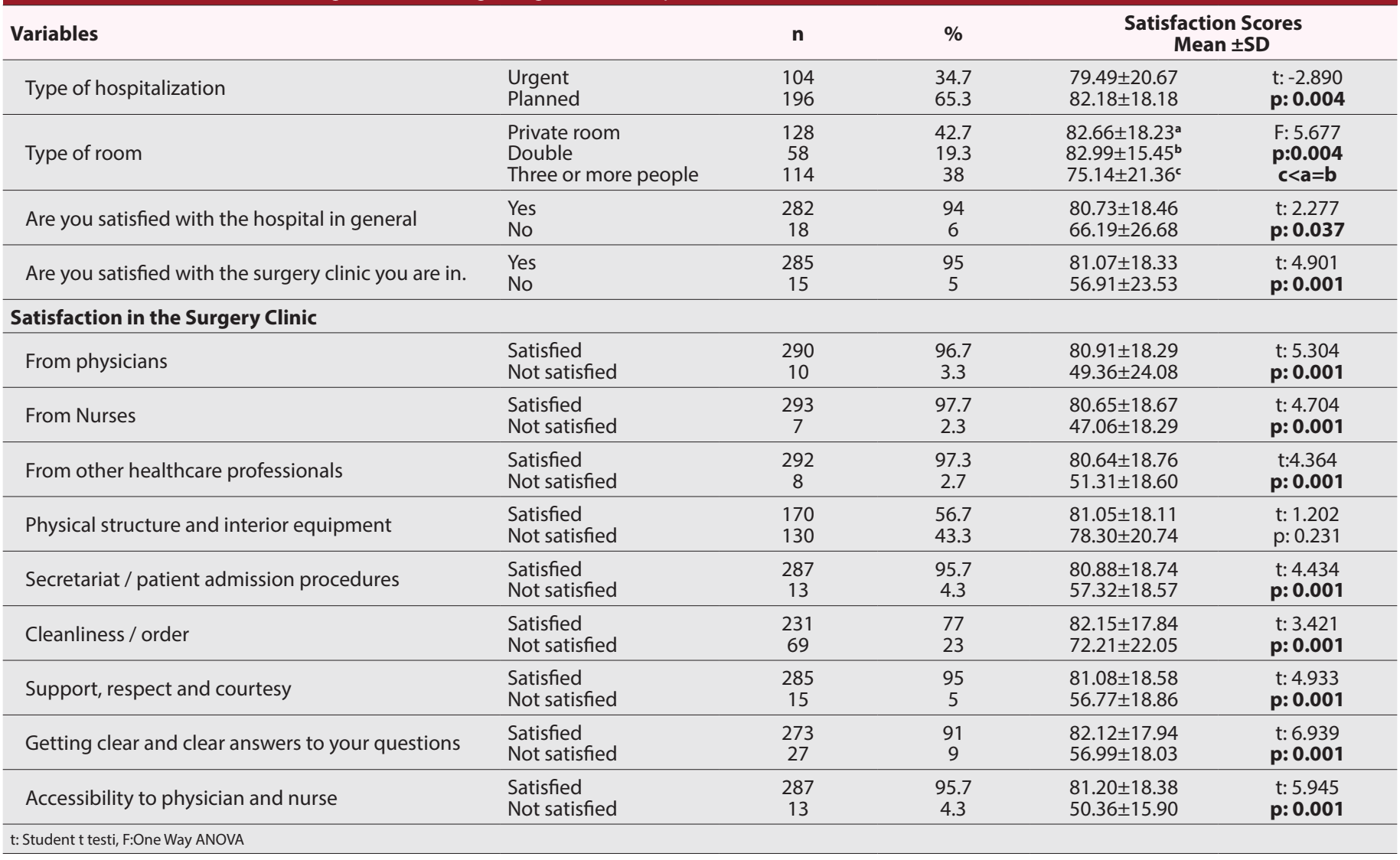

\section{DISCUSSION}

Since surgical interventions cause many physiological and psychological changes in the human body, patients need quality nursing care in this process. ${ }^{[3]}$ The quality of nursing care is directly related to how the given care service is perceived by the service recipients. ${ }^{[5,6]}$ In this study, it was determined that the mean score of the patients' perception of nursing care scale was $68.03 \pm 9.87$ and the surgical patients' perception of nursing care was high. In a study conducted by Çoban and Kaşıkçı (2006), it was found that patients received an average score of $54.44 \pm 12.31$ from PPHEN. ${ }^{[19]}$ In this study, it was seen that the surgical patients had a higher level of perception of nursing care. It was determined that the patients agreed with the statement "I felt well cared for thanks to the nurses" at the highest rate (78\%), and they the least agreed with the statement "Nurses thought more than I needed" (61.3\%). Kol et al. (2017), it was determined that the highest mean score of the PPHEN item belonged to the statement "I felt that I was well cared for thanks to the nurses" and "I am sure that the nurses will be there when I need them".[7] In the study of Şişe (2013), it was found that patients agreed with the statement "I felt well cared for thanks to the nurses" at the highest rate $(72.2 \%)$, while the lowest rate was with the statement "They gave information about things I did not know about the hospital" $(58 \%, 8)) .{ }^{[14]}$ The study by Zhao and Akkadechanunt (2011) found that the patients' perceptions of nursing care were positive and that " nurses were with me when I needed them" had a high participation rate. ${ }^{[20]}$ The perception of care quality such as knowing the patient with the technical skills of nurses, establishing a relationship of trust with him/her, making the patient feel his/her presence, etc. are possible by making the patient feel such care behaviours. ${ }^{[5]}$ In studies with PPHEN, it can be said that patients have a positive perception in terms of their feeling well cared for thanks to nurses.

Patients ' satisfaction with nursing care is the most basic determinant of their overall satisfaction during their hospital care and the best indicator of health service quality. ${ }^{[11,12,21]}$ In this study, it was defined that patients hospitalized in surgical clinics had high levels of satisfaction with nursing care. While this finding showed that the satisfaction of patients hospitalized in surgical clinics about nursing was at a high level in the studies of Kuzu and Ulus (2014) ${ }^{[4]}$, Yıldız et al. (2014) $)^{[22]}$ and İçyeroğlu and Karabulut (2011) $)^{[23]}$, It was found that it was at a moderate level in the study of Kayrakçı and Özşaker (2014) ${ }^{[24]}$, Akgöz et al. (2017) $)^{[25]}$ and Aldemir et al. $(2018)^{[26]}$ and at a low level in the study of Sayın et al. (2016) [27] Given this information, it can be said that the satisfaction of patients in surgical clinics with nursing care varies between low and high levels. This situation may be due to factors such as different nursing standards in research institutions and different number of patients for per nurse. 
Patients' satisfaction with nursing is an important indicator concerning the quality of the nursing services offered. ${ }^{[1]}$ Patient satisfaction is determined by the level of perception of the care given in line with the patient's expectations. ${ }^{[15,16]}$ In this study, a statistically significant and positively high correlation was found between the total score average of the Newcastle Nursing Satisfaction Scale and the total score of the Perception of Nursing Care Scale $(r=0.665 ; p=0.001)$. It was seen that as the patients' perception of nursing care increased, their level of satisfaction also increased. As is also understood from this result, when surgical patients have a positive perception of nursing care, their satisfaction with nursing care increases.

The perception factor varies according to the patient's expectations and individual characteristics from the institution or service. ${ }^{[9]}$ The studies indicate that there is a relationship between patients' perception of nursing care and their social status, age, education level, cultural background and ethnic structure. ${ }^{[28-30]}$ In this study, when the mean PPHEN scores were examined according to the sociodemographic characteristics of the patients; it was found that there was no statistically significant difference between them according to gender, education status, occupation, residence, social security status and chronic disease $(p>0.05)$. When the mean NSNS scores were analyzed according to the sociodemographic characteristics of the patients; it was observed that there was no statistically significant difference between the mean scores of NSNS with gender, marital status, occupation, residence, social security status $(p>0.05)$. Similarly, in the study done by Aldemir et al. (2018) ${ }^{[26]}$, no significant difference was found between the patients' satisfaction with nursing in terms of sociodemographic characteristics such as age, marital status, occupation, having social security and previous hospital experience $(p>0.05)$. In the study, it was found that there was a statistically significant difference between education level and mean scores of NSNS $(p<0.05)$. While the satisfaction levels of the patients graduated from a university with nursing care were low, literates and primary school graduates were found to have higher satisfaction levels. As the education level increased, patients' satisfaction from nursing care decreased. Similarly, it was observed that the low educated patients were more satisfied with nursing care than the highly educated patients. ${ }^{[1,4,21,24,31]}$ The increase in the education level of the society leads to the emergence of the individuals who are more knowledgeable and critical of the service provided, who become more active in their care, and the demands and/or expectations of the individuals constantly change. ${ }^{[13]}$ It is emphasized that the satisfaction concerning nursing is proportional to the expectations, the expectations increase as the level of education increases, and it is stated that the satisfaction level of the patients with high education level is low. ${ }^{[7,26]}$ Thereby, the expectation levels of the sick individuals about the service delivery in the field of health increase and this situation affects the perception of satisfaction. In the light of these findings, it is thought that as the level of education increases, individuals become more conscious, their expectations from the service they receive rise, and as a result, the level of satisfaction with the service received decreases.

Patients with chronic diseases, frequent visits to the hospital and hospitalized for a long time can see the educator, consultant and other roles of the nurse in the clinics where they receive service. ${ }^{[7]} A$ study conducted by Dikmen and Yilmaz (2016) also found that patients with chronic diseases have a higher perception of nursing care. ${ }^{[30]}$ In this study, while there was no significant relationship between having a chronic disease and the perception of nursing care ( $p>0.05)$, it was determined that the patients with chronic disease had a significantly higher level of satisfaction with nursing than those who did not $(p<0.05)$.

When the mean scores of NSNS were examined according to the hospitalization status of the patients: the patients' satisfaction score averages were found to be statistically significantly higher $(p<0.05)$ according to the method of hospitalization, the number of the patients in the room, the state of satisfaction with the hospital in general, the state of satisfaction with the surgical clinic in which they were admitted. It was found that those who stayed in triple rooms and above had lower levels of satisfaction with nursing care than those who stayed in a private room and double room. Similarly, some studies indicate that as the number of beds in the room where the patients are staying increases, their satisfaction scores related to nursing care decrease. ${ }^{[7,32]}$ It was determined that there was no statistically significant difference between the satisfaction levels of surgical patients and their satisfaction with the physical structure and internal equipment ( $p>0.05)$. In the study of Kayrakçı and Özşaker (2014), the satisfaction score averages of the patients who were informed about the physical environment/functioning of the service and the treatment/care applied and who were satisfied with the communication established by the nurses were found to be statistically significantly higher. ${ }^{[24]}$ In the research of Arslan and Kelleci (2011), the most important areas of patients were the ability of nurses to perform the service reliably and correctly, as well as the ability of nurses to establish knowledge, respect and empathy. ${ }^{[28]}$ The least important service area was found to be physical facilities, and these results are similar to our study results.

\section{CONCLUSIONS}

As a result of the research, it was found that surgical patients had high levels of perception of nursing care and high levels of satisfaction with nursing care. It was determined that the patients' perceptions of nursing care positively affected their satisfaction level with nursing care. It was determined that the educational level of the patients, the status of having chronic disease, the number of patients in the room, and the status of satisfaction with the surgical clinic affected the satisfaction 
with nursing care. In line with these results obtained from the study, to increase the satisfaction of the patients hospitalized in surgical clinics in terms of nursing; about ensuring the continuity of nursing services quality by regularly evaluating the perception of patient care, conceiving the factors affecting the satisfaction level while providing care, individualising the patient care considering patient characteristics, making improvements in multi-person patient rooms, in-service training on the subject and with priority in areas where satisfaction is low, in-service training programs may be recommended.

\section{Limitations}

This study results cannot be generalized to the whole of surgical patients' population in Turkey, as the study was conducted in only a university hospital.

\section{ETHICAL DECLARATIONS}

Ethics Committee Approval: Ethics committee approval was obtained from the Clinical Research Ethics Committee of the relevant university (Protocol: 20/03/2018, 18-3.1/31), and written permission was obtained from the management of the hospital where the research was conducted (04.06.2018, E. 159252).

Informed Consent: All patients signed the free and informed consent form.

Referee Evaluation Process: Externally peer-reviewed.

Conflict of Interest Statement: The authors have no conflicts of interest to declare.

Financial Disclosure: This study was supported by the Ege University Scientific Research Projects Coordination Unit. Project Number:TLP-2019-20440.

Author Contributions: All of the authors declare that they have all participated in the design, execution, and analysis of the paper, and that they have approved the final version.

Acknowledgment: We would like to thank the Ege University Coordinator of Scientific Research Projects, which financially supported this study (Project No: TLP-2019-20440), and the volunteers who participated to this study.

Note: This study was presented as a poster presentation at the $3^{\text {rd }}$ International \& $11^{\text {th }}$ National Surgery and Operating Room Nursing Congress, 3 - 6 October 2019 Çeşme, and received the Poster Paper First Prize.

\section{REFERENCES}

1. Cerit B. Hastaların Hemşirelik Bakımından Memnuniyet Düzeyi. Hacettepe Üniversitesi Hemşirelik Fakültesi Dergisi 2016; 3(1): 27-36.

2. Göçmen Baykara Z. Hemşirelik Bakımı Kavramı. Türkiye Biyoetik Dergisi 2014; 1(2): 92-99.

3. Karabulut N, Çetinkaya F. Cerrahi Kliniklerinde Çalışan Hemşirelerin Hasta Bakımında Karşılaştıkları Güçlükler ve Motivasyon Düzeyleri. Anadolu Hemşirelik ve Sağlık Bilimleri Dergisi 2011; 14(1):14-23.

4. Kuzu C, Ulus B. Cerrahi Kliniklerde Tedavi Gören Hastaların Aldıkları
Hemşirelik Bakımından Memnuniyet Durumlarının Belirlenmesi. Acıbadem Üniversitesi Sağlık Bilimleri Dergisi 2014; 5(2):129-134

5. Wysong PR, Driver E. Patients' perceptions of nurses' skill. Critical Care Nurse 2009; 29: 24-37. doi: 10.4037/ccn2009241

6. Hajinezhad ME, Azodi P. Nurse Caring Behaviors from Patients' and Nurses' Perspective: A Comparative Study. European Online Journal of Natural and Social Sciences 2014; 3: 1010-7.

7. Kol E, Geçkil E, Arıkan C, IIlter M, Özcan Ö, Şakırgün E, Dayan Ü, Uygun G, Kılıç D, Macit M, Uslular E, Sızlı A, Çakır N, Solak D, Kavgacı A, Sabancıoğulları S, Atay S. Türkiye'de Hemşirelik Bakım Algısının İncelenmesi. ACU Sağlık Bil Derg 2017; (3): 163-172.

8. Gül S, Dinç L. Hastaların ve Hemşirelerin Hemşirelik Bakımına Yönelik Algılarının İncelenmesi. Hacettepe Üniversitesi Hemşirelik Fakültesi Dergisi 2018; 5(3): 192-208 DOI: 10.31125/hunhemsire.500787

9. Samina M, Qadri GJ, Tabish SA, Samiya M, Riyaz R. Patient's perception of nursing care at a large teaching hospital in India. Int J Health Sci (Qassim) 2010;2:92-100.

10. Twayana S, Adhikari RH. Patient's Perception Regarding Nursing Care at Inpatient Department of Hospitals in Bhaktapur District - published at: "International Journal of Scientific and Research Publications (IJSRP) 2015; 5(5):1-3.

11. Alasad J, Tabar N, AbuRuz M.E. Patient satisfaction with nursing care: Measuring outcomes in an international setting. Journal of Nursing Administiration 2015; 45(11): 563-568.

12. Koirala M, Koirala ML. Contributing factors for perceived satisfaction with nursing care among inpatients in general wards. Journal of Lumbini Medical College 2015; 3(2): 34-7. doi: 10.22502/jlmc. v3i2.69

13. Karaca A, Durna Z. Hemşirelik Bakım Kalitesi ve İlişkili Faktörler. Sağlık ve Toplum 2018; 28(2): 16-23.

14. Şişe Ş. Hastaların hemşirelik hizmetlerinden memnuniyeti. Kocatepe Tıp Dergisi 2013; 14(2): 69-75.

15. Sayed HY, Mohamed HA, Mohamed EE. Patients' perceptions as indicators of quality of nursing service provided at Al Noor Specialist Hospital at Makkah Al Moukarramah, KSA. Journal of American Science 2013; 9: 11-8.

16. Ervin NE. Does patient satisfaction contribute to nursing care quality? Journal of Nursing Administration 2006; 36: 126-30.

17. Uzun Ö. Hemşirelik Bakım Kalitesi İle İlgili Newcastle Memnuniyet Ölçeğinin Türkçe Formunun Geçerlilik ve Güvenilirliğinin Saptanması. Türk Hemşireler Dergisi 2003; 54(2): 16-22.

18. Akın S, Erdoğan S. The Turkish version of the Newcastle Satisfaction with Nursing Care Scaleused on medical and surgical patients. Journal of Clinical Nursing 2007; 16(4): 646-653.

19. Ipek Coban G, Kasikci M. Reliability and validity of the scale of patient perception of hospital experience with nursing care in a Turkish population. J Clin Nurs. 2010 Jul;19(13-14):1929-34. doi: 10.1111/j.13652702.2009.03125.x. PMID: 20920019.

20. Zhao SH, Akkadechanunt T. Patients perceptions of quality nursing care in a Chinese hospital. International Journal of Nursing and Midwifery 2011:3:145-9.

21. Geçkil E, Dündar Ö, Şahin T. Adıyaman il merkezindeki hastaların hemşirelik bakımından memnuniyet düzeylerinin değerlendirilmesi. Hacettepe Üniversitesi Sağlık Bilimleri Fakültesi Hemşirelik Dergisi 2008; 15(2): 41-51.

22. Yıldız T, Önler E, Başkan B, Koluaçık B, Malak A, Özdemir A. ve ark. Cerrahi birimlerde yatan hastaların hemşirelik hizmetlerinden memnuniyet düzeylerinin belirlenmesi. Uluslararası temel ve klinik Tıp Dergisi 2014; 2(3): 123-30.

23. İçyeroğlu G, Karabulutlu E. Hastaların hemşirelik bakımından memnuniyet düzeylerinin belirlenmesi. Fırat Sağlık Hizmetleri Dergisi 2011; 6(17): 67-81.

24. Kayrakçı F, Özşaker E. Cerrahi hastalarının hemşirelik bakımından memnuniyet düzeylerinin belirlenmesi. Florence Nightingale Hemşirelik Dergisi 2014; 22(2): 105-113.

25. Akgöz N, Aslan A, Özyürek P. Nöroşirürji hastalarının hemşirelik bakımı 
ile ilgili memnuniyet ve beklenti düzeylerinin incelenmesi. Uluslararası Hakemli Hemşirelik Araştırmaları Dergisi 2017; 9(9): 73-92.

26. Aldemir K, Gürkan A, Taşkın Yılmaz F, Karabey G. Examination of Satisfaction from Nursing Care of Inpatients in the Surgical Clinics 2018; 5(3): 155-163.

27. Sayin $\mathrm{Y}$, Cengiz OH, Ayoglu T. Nursing care satisfaction of surgery patients. SOJ Nuring Health Care 2016; 2(2): 1-8. https://doi.org/10.15226/24716529/2/2/00116

28. Arslan Ç, Kelleci M. Bir üniversite hastanesinde yatan hastaların hemşirelik bakımından memnuniyet düzeyleri ve ilişkili bazı faktörler. Anadolu Hemşirelik ve Sağlık Bilimleri Dergisi 2011; 14(1): 1-8.

29. Koberich S, Feuchtinger J, Farin E. Factors influencing hospitalized patients' perception of individualized nursing care: a cross-sectional study. BMC Nurs 2016; 15:14. doi: 10.1186/s12912-016-0137-7

30. Dikmen Y, Yılmaz D. Patient's Perceptions of Nursing Care - A Descriptive Study from Turkey. Ann Nurs Pract 2016; 3: 1048.

31. González-Valentín A, Padín-López S, de Ramón-Garrido E. Patient satisfaction with nursing care in a regional university hospital in southern Spain. J Nurs Care Qual 2005; 20: 63-72.

32. İçli GE, Kuğuoğlu S, Aslan FE. Sosyodemografik değişkenlerin hasta memnuniyetine etkisi. Marmara Üniversitesi İdari İktisadi Bilimler Fakültesi Dergisi 2006; 21: 383-400. 